\title{
The Evaluation of Frozen Strawberries Quality by Studying the Kinetics Change of the Antioxidants Activity
}

\author{
Elisaveta Sandulachi (Corresponding author) \\ Technical University of Moldova, 168, Stefan cel Mare Avenue \\ Chisinau, MD-2004, Republic of Moldova \\ Tel: 373-6850-4188Ｅ-mail: luiza_sandulachi@yahoo.com \\ Tatarov Pavel \\ Technical University of Moldova, 168, Stefan cel Mare Avenue \\ Chisinau, MD-2004, Republic of Moldova \\ Tel: 373-2232-1946_E-mail: p_tatarov@yahoo.com \\ Diana Croitor \\ Technical University of Moldova, 168, Stefan cel Mare Avenue \\ Chisinau, MD-2004, Republic of Moldova \\ Tel: 373-7944-6171_E-mail: croitordiana88@yahoo.com
}

\author{
Received: November 11, $2011 \quad$ Accepted: November 25, $2011 \quad$ Published: February 1, 2012 \\ doi:10.5539/jfr.v1n1p225 \\ URL: http://dx.doi.org/10.5539/jfr.v1n1p225
}

\begin{abstract}
This paper presents the study results on quality assessment of frozen strawberries estimating the inetics change of antioxidant activity of fruit during storage.

Fresh strawberries purchased from the trading system were used for the research. The study was conducted over 3 years. A total of 60 batches of strawberries harvested in Moldova were analyzed, from each batch were estimated three samples.

It was appreciated the content of antioxidants: L-hidroascorbic acid, anthocyanins, total polyphenols and reducing activity of fruit. The precision of the characteristics determination for oxido-reducing state of fruit samples $(\mathrm{K}, \mathrm{mg} \mathrm{AA} / \mathrm{g} \mathrm{SH})$ is obtained with the trust coefficient $\mathrm{P}<0.01$ or $\mathrm{P}<0.05$, deviation error limit being \pm $(0.2 \ldots 0.8) \%$ from the average values of the $\mathrm{K}$ indicator. The correlation of the total hydrosoluble antioxidants content (ascorbic acid, anthocyans, polyphenols) and the oxido-reducing state indicator of the fruit (K) attests the values of the Pearson coefficient (R) within $0.88 \ldots 1.0$ and has a functional dependence. The validity of frozen fruit was demonstrated by determining the probability of quality modification of frozen strawberries.
\end{abstract}

Keywords: Frozen strawberries quality, Antioxidant activity, Oxido-reducing state, Hydrosoluble antioxidants, Pearson coefficient

\section{Introduction}

The quality of a product is given by macronutrients and micronutrients content. To assess the nutritional value of fruit products a special attention is paid to the content of bio antioxidants - biologically active substances. From the viewpoint of the scientists from different countries, the antioxidants play a protective role in preventing the cardiovascular diseases, diabetes, gastrointestinal diseases and have a positive role on lifetime, maintaining youth and reducing the oxidative stress (Ivan, 2007; Becker et al., 2004; Proteggente et al., 2002).

In general, the current scientific studies suggests that the colored fruits and vegetables are important sources of antioxidants, provide the necessary of vitamins, minerals and fibers for a proper health, protects against the 
effects of aging and reduce the risk of cancer and the cardiovascular diseases (Olsson et al. 2006; Kiss, et al. 2005; Becker et al., 2004).

These new findings confirm and expand on the results of three studies published in 2003, 2005 and 2006, which show that strawberry extracts can reduce the growth rate of human lung and liver cancer cells, and mouse skin cancer cells, to substantial extents (Olsson et al., 2006; Ramos et al., 2005; Wang et al., 2005; Meyers et al., 2003).

Strawberries are delicious fruits, with a good smell and taste, nice appearance. That is why they are requested fresh. Their sensory properties are determined by the presence of phenol substances and anthocyanins. Strawberry are an excellent source of vitamin $\mathrm{C}$ and manganese. They are also a very good source of dietary fiber and iodine. Plus, strawberries are a good source of potassium, vitamin B2, vitamin B5, vitamin B6omega -3 fatty acids, vitamin K, magnesium, and copper (Ivan, 2007; Wang et al., 2005; Gherghii et al., 2001). Strawberry also contain an array of beneficial phytonutrients, including flavoinoids, anthocyanidins and ellagic acid ( Wang et al., 2005; Sandulachi, 2005; Gherghii et al. 2001; Proteggente et al., 2002).

Srtawberries, like other berries, are famous in the phytonutrient world as a rich surce of phenols. In the strawwberry, these phenols are led by the anthocyanins (especially anthocyanin 2 ) and by the ellagutannins. The anthocyanins in strawberry not only provide its flush red color, they also serve as potent antioxidants that have repeatedly been shown to help protect cell structures in the body and to prevent oxygen damage in all of the body's organ systems. Strawberries unique phenol content makes them a heart-protective fruit, an anti-cancer fruit, and an anti-inflammatory fruit, all rolled into one (Wang et al., 2005; Proteggente et al., 2002).

The strawberry, like many other perishable fruits suffer changes in time. Strawberries are perishable and under the action of peroxidase enzymes that contribute to the appearance of brown compounds and the loss of smell, they support permanent changes of phenol substances (their oxidation) (Tatarov et al., 2010; Sandulachi et al., 2010; Croitor et al., 2010 ; Wang et al., 2005; Gherghii et al. 2001; Duckworth, 1975).

The results (Proteggente et al., 2002) indicate that fruits soch as strawberry are an excellent source of phenolics and vitamin $\mathrm{C}$ and therefore possess an extremely high antioxidant potential in fact, the anthocyanins, which are the major class of phenolics inthis type of fruits, generally have demonstrated high antioxidant activity in vitro systems.

During storage and processing, the content of these substances is reduced according to their involvement in the process of oxido -reduction. Their evolution depends on several factors, as: the chemical composition of the fruits, parameters of the technological process, storage conditions, etc (Tatarov et al., 2010; Banu et al., 2004; Banu et al., 2003; Mihalca et al., 1986).

We need to mark that the conservation through freezing is one of the most effective method of preserving the perishable fruits quality. Commonly, strawberries are preserved by freezing and stored frozen. In industrial conditions frozen strawberries are usually kept at the temperature of $-18^{\circ} \mathrm{C}$ (Banu et al., 2004; Banu et al., 2003). At the same time, the congealed products in storage period suffer some modification of sensory characteristics and nutritional value (Sandulachi et al., 2006; Marfart, 1996; Mihalca, et al., 1986; Saguy et al., 1980).

\section{Materials and Methods}

\subsection{Cnemicals}

Folin-Ciocalteu phenol reagent, gallic acid monohydrate, glacial acetic acid, L-ascorbic acid, sodium carbonate was obtained from EM Science, alcohol, hydrochloric acid.

\subsection{Fruits}

For oficial examination were used autochthonous strawberry, acquired and trade network. There were evaluated a total of 60 batches of strawberries, harvested in R. Moldova during three years. Strawberry samples were frozen and kept at the temperature of minus $18^{\circ} \mathrm{C}$ for 10 months. Experimental studies have been performed for the following varieties: Victoria, Sega-Segana, Frumuşica. The study was conducted both for fresh and frozen strawberries. The estimation of the reducing state of frozen strawberries was carried out in samples stored 3, 6 to 10 months. It was evaluated the dependency between the reducing state of frozen strawberries on bio antioxidants content and the influence of the technological process on the quality of strawberries.

\subsection{Sample freezing}

The samples were congealed in „Ghiocel” freezer at the temperature of $-18^{\circ} \mathrm{C}$. Before congelation preventive operations were made: sorting, washing, top water-drying. The samples were packed in polisterol bags or $\mathrm{Al} / \mathrm{bald}$ with weight $30.0-50.0 \mathrm{~g}$. Before being hermetically closed, the samples were treated with $\mathrm{N}_{2}$ for 
reducing the $\mathrm{O}_{2}$ strength. For freezing the samples it was performed the following scheme: reception of raw material $\rightarrow$ Washing $\rightarrow$ Inspection $\rightarrow$ Removing water from the surface (through vibrating and air blowing) $\rightarrow$ Weighting the samples $(\mathrm{g}) \rightarrow$ Packaging, polystyrene packages, aluminium foil. Sample mass $30-50 \mathrm{~g} \rightarrow$ Vacuuming and nitrogen treatment (Pressure value $\mathrm{P}=1.5 \mathrm{~atm}$., for 2-3 minutes) $\rightarrow$ Tightening the packages $\rightarrow$ Freezing at $-18^{\circ} \mathrm{C}$, freezer $\rightarrow$ Storage. Depositing the frozen samples $\left(\mathrm{t}=-18^{\circ} \mathrm{C}\right.$, for 3,6 and 10 months). Nitrogen $\left(\mathrm{N}_{2}\right)$ was used to remove the air from the package, in order to have anaerobic conditions (prevents aerobic spoilage and oxidative degradation of bioantioxidants).

\subsection{Thawing of samples}

Rapid thawing (temperature of $98^{\circ} \mathrm{C}$, for $1-2$ minutes), for the samples in which was determined the content ascorbic acid, polyphenols and anthocyanins. Slow thowning (room temperature, for 30 minutes) for the samples in which was investigated the loss of juice during thawing. In fresh samples and in the congealed one, was estimated the antioxidant capacity, acid ascorbic through method potentiometric (GOST 24556-81, 1981); total pholyphenol content through Folin-Ciocalteu method (Snegiryova et al., 1976); total anthocyanins content through physical-chemical method (Snegiryova et al., 1976); and property of redox state, expressed with K-index, $\mathrm{mg} \mathrm{AA} / \mathrm{g}$ HS (Macari et al., 2005).

\subsection{Tested indicators}

There were determined the following indicators in the samples: content of soluble substances, the active acidity, $\mathrm{pH}$, the maturity and the content of bio antioxidants: ascorbic acid by potentiometric method, total polyphenols by Folin-Ciocalteau method, total anthocyanins by the standard physicochemical method. Also, it was assessed the oxido-reducing state of strawberries by potentiometric method, expressed by the oxido-reducing index (K) (Sandulachi, 2006; Sandulachi et al., 2006; Macari et al., 2005;). The interdependence of reducing state of frozen strawberries and the content of ascorbic acid, anthocyanins and total polyphenols were assessed by processing statistically the experimental data. (Sandulachi, 2006 "a"; "b"; Sandulachi et al., 2006; Гутер et al., 1970). Pearson correlation coefficient was determined by using Microsoft Excel program.

\subsection{General principles of evaluation of redox state}

Generally speaking, the process of oxidation and reduction is evaluated according to the rate of redox potential of a closed system, in our case - food product (Шульц et al., 1984;). The fixed value of redox potential is a sign of equilibrium state in all the redox couples of food. Redox couples represent multiple redox reactions of chemical compounds, including bioantioxidants from food. The principle of the elaborated method is based on the laws of chemical thermodymanics, by forming the equilibrium state between two separate systems-product and etalon system. Two electrochemical cells were used with aim. In each cell there were introduced two electrodes: platimum electrode and silver electrode. The silver electrodes were connected to each other, platinum electrodes were connected to the potentiometer. In one cell there was introduced a food sample for testing and in the other one-the etalon solution. According to Nernst equation the redox potential of etalon system-ascorbic acid and the redox potential of the tested food (Macari et al., 2005). The ratio:

$$
\lg \left\{\frac{\left[\mathrm{AA}_{o x}\right]}{\left[\mathrm{AA}_{\text {red }}\right]} / \frac{\left[\sum P_{o x}\right]}{\left[\sum P_{\text {red }}\right]}\right\}=K
$$

Is a relation with constant value and it is expressed by the $\mathrm{K}$ coefficient. Relation (1) shows the ratio between ascorbic acid concentration and the concentration of the tested product in equilibrium state $\left(E_{l}=E 2\right)$. The $\mathrm{K}$ coefficient is a constant index that depends on the values of standard potential of ascorbic acid and values of standard formal potential of the food product (Macari et al., 2005).

\subsection{The experimental method for assessing the redox state}

Before the determination, raw material was preventively thermally treated at $+96^{\circ} \mathrm{C}$ during $2-3$ minutes, then it was homogenized, $10-15 \mathrm{~g}$ of sample was diluted in proportion of 1:1 using distillated water and was introduced in the measuring cell. In cell II was introduced buffer solution with $p \mathrm{H}$ of the analyzed product - the reference solution. After the thermo stating of sample at $20^{\circ} \mathrm{C}$, electrodes of platinum and silver chloride are introduced in cells. We register the difference between the redox potentials of cells, and in cell II we dose the etalon solution (ascorbic acid) until there is equality between the potentials of cell I and II. The potentiometer shows $\mathrm{E}=0$. The redox state of the tested products is expressed by the $\mathrm{K}$ coefficient as ascorbic acid equivalent $\mathrm{mg}$ per $\mathrm{g}$ product hydrosoluble solids (HS). The K coefficient is calculated using the following relation: 


$$
K=\frac{C_{1} \times V_{1} \times m_{1}}{m_{2} \times C_{2} \times m_{3}}
$$

where: $C_{1}$ - concentration of the etalon solution, $\mathrm{mg} / \mathrm{ml}$;

$C_{2}$ - the mass fraction of hydrosoluble solids, $\mathrm{g} / \mathrm{g}$;

$V_{l}$ - the volume of the etalon solution of ascorbic acid that is equivalent to the redox potential of the tested system, $\mathrm{ml}$;

$m_{1}$ - the mass of the analyzed sample after dilution, g;

$m_{2}$ - the mass of reference solution, $\mathrm{g}$;

$m_{3}-$ the mass of the analyzed sample, g.

\section{Discussion and Suggestions}

Sensorial analyze of frozen strawberry appearance showed that the fruit color remained almost the same compared to the fresh fruits. We observed just a weak appearance of brown color. Analyzing the contents of L-hidroascorbic acid, pholyphenols and whole anthocyanins it was observed a diminution of these indexes on depositing way. Medium values are presented in Table 1. Higher shown index diminution was different: depending by the staple primary quality, staple procession previous freezing, keeping term and pack quality.

The antioxidants activity consists the biological value of the fruits. These indicators are directly proportional (Tatarov et al., 2005: Proteggente et al., 2002). The biological value of the product is higher with the increasing of the reducing activity. The basic index that characterize the reducing activity of the antioxidants is oxido-reducing condition (Tatarov et al.,2005; Sandulachi, 2006, "b"; Macari et al., 2005). As the chemical composition of strawberries, including content and antioxidant activity was very variable, the experimental data were analyzed by statistical methods, using the probability theory Sandulachi, 2006, "b"; Sandulachi, 2006, "c"; Sandulachi et al. 2006).

It was found that there is a slow degradation of antioxidants in the frozen strawberries in the first three months of storage. At a longer storage - the oxidative degradation of antioxidants is faster. The study reveals a decrease in: polyphenol content within 15.2 - 66.6\%, anthocyanin content within $6.85-37.83 \%$, and L-Hydroascorbic acid content $7.15-33.25 \%$.

Therefore, it was found that during the storage of frozen strawberries there are changes in the content of antioxidants and their oxido-reducing. Reduction of these features is a function of shelf life and the freezing temperature. Contents diminution in pholyphenols after 10 months at frozen strawberry was medium estimated at $46.18 \%$, contents diminutions in anthocyanins was medium estimated at $23.50 \%$, but contents diminution in ascorbic acid was estimated at $24.72 \%$ (Figure 1).

It was found that in congealed and stored strawberries at the temperature of $-18^{\circ} \mathrm{C}$ there is a slow antioxidant degradation in first months. At a longer depositing period $\left(10\right.$ months, $\left.\mathrm{t}=-18^{\circ} \mathrm{C}\right)$ biologically active substances degrade oxidative at an accelerated rate. The degree of degradations occurs in the following sequence: polyphenols, ascorbic acid, anthocyanins.the content of biologically active substances in dependency of raw material, conditions of storage, processing, freezing and storage (Sandulachi, 2006, "b", "c","d". Sandulachi et al.,2004).

Probably through the water contents in unfrozen decrease we can explain a very big diminution of plolyphenols, ascorbic acid and anthocyanins in investigation samples. The activity and enzymatic reaction speed almost touches the maximal values of water stratums in frozen strawberry. Probably this phenomenon leads at modification the chemical compounds, plus antioxidants and redox state decrease in food environment.

In the frozen products the enzymatic reactions are slower, but not completely blocked. In general, the enzyme activity in frozen strawberries is related to the presence of unfrozen water. At a temperature of minus $18^{\circ} \mathrm{C}$ the water content in frozen strawberries is about $89 \%$ of total water content. The unfrozen water will be $11 \%$. At a temperature of minus $30^{\circ} \mathrm{C}$ the frozen water content will be $91 \%$ of the total water content and $9 \%$ of unfrozen water (Duckworth, 1975).

In this paper there are presented the results of the experimental researches of the oxido-reduction state of strawberries, the influence of the state of berries by the content in active state of the ascorbic acid, of anthocyanines, and total polyphenols during the period (for 3 years). It is also presented the statistical analysis of 
the experimental data of the dependence of the oxido-reduction state of the strawberries on the biologically active substance of the berries: ascorbic acid, anthocyanines and total polyphenols. The correlation coefficient of the oxido-reduction state of the fruits and the content of the biologically active substances was estimated between $0.66 \ldots 0.99$ (Figure 2).

Experimental data obtained are related to bibliographic data. Also, it was evaluated the influence of the technological process on the quality of strawberries preserved by freezing. In industrial conditions, the frozen strawberries are stored at a temperature of minus $18^{\circ} \mathrm{C}$. Several scientists researches shows that during storage there are nutritional values and sensory properties changes in the frozen strawberries and this generated loss of quality. At the same time, it is considered that one of the most effective methods of preserving the quality of the perishable fruits is by freezing. Level of quality of frozen strawberries was achieved by studying changes in the content of antioxidants and the reducing state of fruits during storage.

In general, the oxido-reducing state of strawberries reflects not only the total content of reducing substances, but also the reducing activity of the compounds with major activity. The oxido-reducing state of strawberries is influenced on the content of ascorbic acid, anthocyanins and polyphenols. The study showed that the oxido-reducing state is strongly influenced by the polyphenols content. The correlation cefficient between $\mathrm{K}$ and the polyphenols content was between 0.88 and 0.91 . These results indicate that once again that polyphenols exibits the largest reducing activity (Sandulachi et al., 2006). The Pearson correlation varies within 0.9...0.99 (Figure 3).

Datelor experimentale şi prelucrarea statistică [Sandulachi] demonstrează că există o corelație semnificativă intre starea oxido-reducătoare şi conținutul în bioantioxidanți din căpşune. Cercetările efectuate demonstrează că în căpşune raportul intre conținutul total de substanțe în stare redusă şi în stare oxidantă este deplasat în partea redusă. Conținutul substanțelor reduse este mai mare decît cel al substanțelor oxidate. În general starea oxido-reducătoare a căpşunelor poate fi caracterizată ca stare redusă cu valorile indicelui $\mathrm{K}-11.83-19.93 \mathrm{mg}$ $\mathrm{AA} / \mathrm{g} \mathrm{SH}$.

Analyzing the experimental data it was found that oxido-reducing condition of frozen strawberries is reduced exponentially. As shown Figure 4.

In accordance with the fundamental principles of the kinetics of chemical reactions the change rate of food quality can be expressed by a functional reaction depending on the chemical composition of food and the environmental parameters (Kennth et al., 2004; Saguy et al., 1980):

$$
\frac{d Q}{d \tau}=\mathbf{F}\left(\mathbf{C}_{\mathbf{i}}, \mathbf{E}_{\mathbf{j}}\right)
$$

where: $\frac{d Q}{d \tau}$ - the quality change rate of food;

$\mathbf{Q}$ - is the integrated indicator of food quality;

Ci - intrinsic factors, ie chemical composition of food factors (concentration of various chemical substances, water activity, enzymes, etc.);

Ej - extrinsic factors, ie environmental factors (temperature, relative humidity, radiation and other physical effects).

In this research the $\mathbf{C}_{\mathbf{i}}$ represent the antioxidant content: of L-hydroascorbic acid, polyphenols and total anthocyanins. The quality of frozen strawberries was evaluated by changing the antioxidants activity. So, $\mathbf{C}_{\mathbf{i}}$ indicate the changing of the strawberries activity ( $\mathbf{K}$ index).

$\mathbf{E}_{\mathbf{j}}$ indicator - external factor, represents the freezing and storing temperature $\left(-18^{\circ} \mathrm{C}\right)$.

The integral quality of frozen strawberries $\mathbf{Q}$ was expressed by the reducing activity of the fruits antioxidants. The quality index was presented as follows:

$$
\mathbf{Q}=\mathbf{A}_{\mathbf{0}}
$$

$\mathbf{A}_{\mathbf{0}}$ is the quality of frozen strawberries by reducing activity of antioxidants.

The quality of frozen strawberries $\left(\mathbf{A}_{\mathbf{o}}\right)$ was measured by biological value, meaning the summary activity of antioxidants (L-hydroascorbic acid, polyphenols and total anthocyanins) expressed by $\mathbf{K}$ index. 
In general, the quality change rate of frozen strawberries $\mathbf{A}_{\mathbf{0}}$ during storage at minus $18^{\circ} \mathrm{C}$ is presented by the relationship:

$$
\frac{d Q}{d \tau}=\mathbf{F}\left(\mathbf{K}, \mathbf{t}\left(-18^{\circ} \mathbf{C}\right)\right)
$$

The kinetics of the changing of the antioxidant activity - L-hydroascorbic acid, anthocyanins and total polyphenol content can be summarized as follows:

$$
\frac{d\left(A_{o}\right)}{d \tau}=\mathbf{K}_{\mathbf{i}}\left[\mathbf{A}_{\mathbf{0}}^{\mathrm{I}}\right]^{\mathrm{n} 1}\left[\mathbf{A}_{\mathbf{0}}^{\mathrm{II}}\right]^{\mathrm{n} 2}\left[\mathbf{A}_{\mathbf{0}}^{\mathrm{III}}\right]^{\mathrm{n} 3}
$$

where: Ao is the general value of antioxidant activity, expressed by $\mathrm{K}$ index.

$\mathbf{A}_{\mathbf{0}}{ }^{\mathrm{I}}, \mathbf{A}_{\mathbf{0}}$ II, $\mathbf{A}_{\mathbf{0}}{ }^{\text {III }}$ - accordingly the activity of L-hydroascorbic acid, anthocyanins and total polyphenols;

$\mathbf{K}_{\mathbf{i}}$ - chemical reaction rate constant;

$\mathbf{n}_{1}, \mathbf{n}_{2}, \mathbf{n}_{3}$ - order of reaction.

In the case of complex systems containing antioxidants (5) the speed of reactions is irreversible.

In strawberries simultaneously presenting real systems, there is an interdependence between content and the antioxidant activity and the chemical composition and the physiological structure of plant tissue. The separation of antioxidants in strawberries will result in destruction of the structure and physic-chemical characteristics of strawberries. The research of the changing of antioxidants in strawberries was performed taking into account these properties. We studied the kinetics of changes in the antioxidant activity.

Equation (5) was simplified by using the integral activity of antioxidants $-\mathbf{A}_{\mathbf{0}}$

$$
-\frac{d\left(A_{o}\right)}{d \tau}=\mathbf{K}_{\mathbf{j}}\left[\mathbf{A}_{\mathbf{0}}\right]^{\alpha}
$$

where: Ao is the total antioxidant activity;

$\boldsymbol{\alpha}$ - the order of the oxidation reaction of the antioxidants;

$\mathrm{Ki}$ - reaction rate constant (Pseudo constant because it is not known the order of the reaction $-\alpha$ ).

First, it is necessary to determine the order of the reaction $\boldsymbol{\alpha}$. Through logarithming the (6) equation, we obtain:

$$
\log \left[\frac{d\left(A_{o}\right)}{d \tau}\right]=-\log \mathbf{K}_{\mathbf{i}}+\boldsymbol{\alpha} \log \left[\mathbf{A}_{\mathbf{0}}\right]
$$

The experimental data form a straight line in the following coordinates $\log \left[\frac{d\left(A_{o}\right)}{d \tau}\right]-\log \left[\mathbf{A}_{0}\right]$ (Figure 5).

The reaction order was calculated through statistical processing. Receiving the coefficient of correlation $\mathrm{R}=0.977$, antioxidants oxidation reaction was of first degree.

Based on the results, the equation (6) can be summarized as follows:

$$
-\frac{d\left(A_{o}\right)}{d \tau}=\mathbf{K}_{\mathbf{i}}\left(\mathbf{A}_{\mathbf{0}}\right)
$$

Equation (8) was used to determine the numerical value of the reaction rate constant $-\mathrm{Kj}$

Integrating the equation (8) we obtain:

$$
\tau K_{1}=\log \left[A_{01} / A o\right]
$$


Where $\mathbf{A}_{\mathbf{0} 1}$ is the initial activity of antioxidants Ao1 ( $\left.\tau=0\right)$

$\mathbf{A}_{\mathbf{0}}$ - the antioxidants activity during the time of preservation of strawberries $(\tau)$.

From the equation (9) was determined the reaction rate constant K1. Experimental data in semi logarithmic coordinates $\log ($ Ao) $-\tau$ (Figure 6) shows a straight line.

The angle $\alpha$ of the straight line (Figure 6 ) is numerically equal to the reaction rate constant $\mathrm{Kj}$ :

$$
K_{j}=0,1065 \% \text { months }
$$

The change in antioxidants activity during storage of frozen strawberries is characterized by the equation:

$$
\log \left(A_{0}\right)=-0,1065+\log \left(A_{01}\right)
$$

$\mathrm{K} 1$ coefficient was used for determining the change in the quality of frozen strawberries Ao during storage at a temperature of $-18^{\circ} \mathrm{C}$.

There were assessed the probability of quality loss during the storage of frozen strawberries.

Because the chemical composition of strawberries, including antioxidant content is extremely variable, it is impossible to assess the change of the quality using equation (10). Equation (10) reflects only the quality changes of strawberries with equal reaction rate constant $\mathrm{Kj}=0.10651 /$ months. In fact, there can be purchased strawberries with different constant values of $\mathrm{Kj}$ and antioxidant activity Ao.

This divergence can be resolved using the probability theory. The problem is to determine the probability of quality loss Ao during storage at the temperature of $-18^{\circ} \mathrm{C}$, for a period of $0 \ldots \tau$ months.

According to equation (10), the experimental data (Figure 5) shows that the evolution of the antioxidants in the examined frozen strawberries (respectively the quality Ao) is subjected to exponential equation:

$$
\mathbf{A o}=\mathbf{A}_{01} * \exp (-\mathbf{0 , 1 0 6 5 \tau )}
$$

For strawberries containing a variable antioxidants content and activity, the equation (11) can be represented in general:

$$
A_{0}=A_{01} \exp (-\lambda \tau)
$$

where $\lambda$ is a parameter of the exponential equation with a constant value, $\lambda=$ const.

According to the probability theory, for the exponential distribution the probability of distribution of density $\varphi$ $(\tau)$ within the limits $(0 \ldots \tau)$ will be [9]:

$$
\left\{\begin{array}{l}
0, \\
\mathbf{A}_{0} \exp (-\lambda \tau), \quad \tau \geq 0
\end{array}\right.
$$

The probability density function $\varphi$ has the following property:

$$
\int_{-\infty}^{+\infty} \varphi(\tau) d \tau=1
$$

Using equation (14), the integral within $[0, \ldots \tau]$, according to the probability distribution function will be:

$$
\int_{-\infty}^{+\infty} \varphi(\tau) d \tau=\int_{-\infty}^{+\infty} A_{o} e^{-\chi \tau} d \tau=-\quad \frac{A_{o}}{\chi} \int_{0}^{\infty}=\frac{A_{o}}{\lambda}
$$

From equation (14) follows: 


$$
\frac{A_{o}}{\lambda} \quad=1, \quad \mathrm{~A}_{\mathrm{o}}=\lambda, \quad \Rightarrow \quad \mathrm{A}_{\mathrm{o}} \mathrm{e}^{-\lambda \tau}=\lambda \mathrm{e}^{-\lambda \tau}
$$

Probability density function F $(\tau)$ is given as (Гутер et al., 1970):

$$
\mathrm{F}(\tau)=\int_{-\infty}^{\mathrm{X}} \varphi(\tau) d \tau
$$

From (15) we get:

$$
\mathrm{F}(\tau)=\int_{-\infty}^{\tau} \varphi(\tau) d \tau=\quad \int_{0}^{\tau} \lambda e^{-\lambda \tau} d \tau=-\mathrm{e}^{-\lambda \tau} \int_{0}^{\tau} d \tau=\lambda \mathrm{e}^{-\lambda \tau}
$$

After calculations we obtain:

$$
1-\mathbf{A}_{0} \exp (-\lambda \tau), \quad \tau \geq 0
$$

The probability of changing of Ao in time is:

$$
\mathbf{P}(\tau)=1-\mathbf{F}(\tau)=1-\mathbf{F}\left(1-\mathrm{e}^{-\lambda \tau}\right)
$$

where $P(\tau)$ is the quality probability of frozen strawberries

Equation (14) is used to calculate the quality probability of frozen product during storage.

$$
\mathrm{P}(0<\tau<\beta)=\mathrm{F}(\beta)-\mathrm{F}(\alpha)=\mathrm{F}\left(1-\mathrm{e}^{-\lambda \tau}\right)-\mathrm{F}\left(1-\mathrm{e}^{-\lambda 0}\right)=1-\mathrm{e}^{-\lambda \tau}-1+1=\mathrm{F}\left(1-\mathrm{e}^{-\lambda \tau}\right)
$$

where $\tau$ is the storage time, months

$$
\mathbf{P}(\tau)=\mathbf{F}\left(1-\mathbf{e}^{-\lambda \tau}\right)
$$

The $\lambda$ parameter characterizes the rate of quality change of the product. In these researches $\lambda=\mathrm{K}=0,1065{ }^{1}$ / months. Physical meaning of $\lambda$ is the speed of reducing activity change of antioxidants.

The corelation (18) reflects the quality level probability of frozen strawberries depending on storage duration $(\tau)$. The quality losses $\mathrm{Q}$ of frozen strawberries are determined by the relationship:

$$
\mathbf{P}(\tau)=\mathbf{1}-\mathbf{F}\left(\mathbf{1}-\mathbf{e}^{-\lambda \tau}\right)
$$

The relationship (19) was used to calculate the probability of quality loss of frozen strawberries (Figure 7).

Figure 4 shows that the first 3 months there has been a slow decrease of quality as the probability of loss is up to $26 \%$. Based on experimental data, it has been determined a slow decrease in antioxidant content and a slight reduction in the reducing state. After 7 to 12 months the probability of storage loss becomes more relevant, up to $50 \% \ldots 71 \%$. Perhaps at a lower freezing temperature $\left(-25 \ldots-30^{\circ} \mathrm{C}\right)$ quality losses of the strawberries were much smaller.

\section{Conclusions}

The oxido-reducing state of strawberries depends on the content of polyphenols, anthocyanins and ascorbic acid. The oxido-reducing state is strongly influenced by the content of polyphenols.

In frozen strawberries, during storage there are nutritional and sensory properties changes, resulting in loss of quality. Quality can be determined by analyzing the kinetics of the changing of the bio antioxidants activity.

It was found that the frozen strawberries stored at a temperature of $-18^{\circ} \mathrm{C}$ in the first three months show a slow degradation of the biologically active substances. At a longer storage $\left(10\right.$ months, $\left.t=-18^{\circ} \mathrm{C}\right)$ the rate of the degradation is accelerated. 
Based on presented methodology is possible to predict the reliability of frozen fruits and also the quality term of maximum nutritional value and the reducing activity of antioxidants.

\section{References}

Banu, C. et al. (2003). Procesarea materiilor prime şi pierderile de substanţe biologic active. Ed. Tehnica, Chişinău, 88-90.

Banu, C. et al. (2004). Principiile conservării produselor alimentare, Ediția AGIR. Bucureşti, 77-113.

Becker, E. M., \& Nissen L.R., (2004). Antioxidant evalution protocols; Food qualitsy or health effects. Eur Food Res. Technol, 219, 561-571. http://dx.doi.org/10.1007/s00217-004-1012-4

Croitor, D., Sandulachi, E., \& Prutean, N. (2010). The dependency of fresh berries oxido -reducing state on ripeness level. Papers of the Sibiu Alma Mater university Conference, Fourth edition, 25/27 March 2010, Sibiu, Volume I, 289-291.

Duckworth, K. B. (1975). Water relations of foods. Academic press, London, 156-164, 376.

Gherghii, A. et al. (2001). Biochimia şi fiziologia legumelor şi fructelor, ed. Academia Română, Bucureşti, 328.

Gil, M. I., Aquayo, E., \& Kader, A. A., (2006). quality chages and nutrient retention in frech-cut versus whole fruits during storage. J. Agric Food Chem, 54(12), 4284-96.

Gorini, M. (1985). La refrigerazione rapida per una qualita superiore . Terra e vita, 26(16), 55-60.

GOST 24556-81. (1981). Producti pisevie conservirovanie plodoovosnie. Metodi opredelenia vitamina C. Izdatelistvo standartov. Moscva, str. 11.

Ivan. L. (2007). Antioxidanţii sunt protectorii sănătăţii noastre, Adevărul, 20 August.

Kennth, I. et al. (2004). Food Engineering Practice CRC Pres, New York, Sankt Peterburg. Professia, 434-477.

Kiss, A., Kowalski, J, et al. (2005). Breast Cancer Linked to Inflammation. Biofactor, 23(4), 197-205.

Klopotek, Y., Otto, K., \& Bohm, V. (2005). Processing strawberies to different roducts alters contents of vitamin C, total phenols, total anthocyanins, and antioxidant capacity. J Agric Food Chem, 13, 53(14), 5640-6.

Labuza, T. P., (1989). Application of chemical kinetics to deterioration of food, J. Food Processing \& Preservation, 13, 1-69. http://dx.doi.org/10.1111/j.1745-4549.1989.tb00090.x

Macari, A., Tatarov, P., \& Sandulachi, E. (2005). Determination of Antioxidant Activity of Vegetables by Potentiometric Metod. Internaţional Symposium Euro-aliment, Galați, România, 12-15.

Marfart, P. (1996). Modification du produit liées à la congélatio; Génie industriel alimentaire, Paris, Tec Doc, 192-203.

Meyers, K., J. et al. (2003). Strawberries. J. Agric Food Chem. 5, 51(23), 6887-92.

Mihalca, G. et al. (1986). Tehnici de păstrare a alimentelor prin frig, Ediţia Tehnică, Bucureşti.

Olsson, M. E. et al. (2006). Organically Grown Strawberries: Preliminary Evidence for Health Benefits in Relation to Colon and Breast Cancer. J.Agric Food Chem, 22, 54(4), 1248-55.

Proteggente, A. R. et al. (2002). The Antioxidant Activity of Regularly Consumed Fruit and Vegetables Reflects their Phenolic and VitaminC Composition. Free adicals Research, 36(2), 217-233.

Ramos, S. et al. (2005). Strawberry. J Agric Food Chem, 53, 4032-40.

Saguy, I. et al. (1980). Modelling of quality deterioration during food processing and storage. Food Technology, $3(2), 78-85$.

Sandulachi E. (2006). Determinarea stării oxido-reducătoare a căpşunilor şi zmeurii de conținutul în acid ascorbic, antociane şi polifenoli totali. Meridianul Ingineresc, U.T.M., Chişinău, 3, 48-52.

Sandulachi, E. (2005). Căpşunele şi zmeura - surse majore de bioantioxidanţi. Agricultura Moldovei, nr.6, 26-28.

Sandulachi, E. (2006). Interdependenţa dintre starea reducătoare şi conținutul în bioantioxidanţi al căpşunelor şi zmeurii, Materialele conferinței jubiliare (40 ani) a doctoranzilor, Chişinău, 109-111.

Sandulachi, E. (2006). Modificarea conținutului în polifenoli, antociane şi acid ascorbic în căpşune. Agricultura Moldovei, 9, 23-25.

Sandulachi, E., \& Tatarov, P. (2006). Determinarea stării reducătoare a căpşunelor congelate de conţinutul în acid ascorbic, antociane şi polifenoli totali, 2006, Meridianul Ingineresc, U.T.M., Chişinău, 4, 93-97. 
Sandulachi, E., Tatarov, P., \& Croitor, D. (2010). The estimation of dependency of fresh berries physico-chemical properties on storage and processing conditions, Annals. Food Science and Technology, 13-15.

Snegiryova, I. et al. (1976). Sovremennie metodi issledovania cacestva pisevih producto. Izdatelistvo Econimica, Moscova.

Tatarov, P., \& Sandulachi, E., (2010). Chimia produselor alimentare. Ciclul de prelegeri. Partea 3.Chişinău, p.3-70p.160.

Tatarov, P., Ivanova, R., \& Macari, A., (2005). Activitatea biontioxidanţilor unor specii de materii prime vegetale, Meridianul Ingineresc, nr.4, U.T.M., Chişinău, 93-95.

Wang, S. Y. et al. (2005). STRAWBERRY. J. Agric Food Chem, 53, 4032-40.

Гутер, Б. В. \& Овчинский, Б. В. (1970). Элементы численного анализа и математической обработки результатов опыта. Издательство Наука, M, 209-245.

Шульц, М.Н. et al. (1984). Окислительный потенциал. Ленинград, 45-60.

Table 1. The modification of antioxidants in congealed strawberry during stor

\begin{tabular}{|c|c|c|c|c|c|c|c|c|}
\hline \multirow{2}{*}{$\begin{array}{l}\text { The } \\
\text { average } \\
\text { walue } \\
\text { of the } \\
\text { annual } \\
\text { sample }\end{array}$} & \multicolumn{3}{|c|}{ Antioxidants content, $\mathrm{mg} / 100 \mathrm{~g}$} & \multirow{2}{*}{$\begin{array}{l}\text { Redox state } \\
\text { decrease K, } \\
\text { mg AA/g HS }\end{array}$} & \multicolumn{4}{|c|}{$\begin{array}{l}\text { The correlation coefficient Pearson } \\
\text { between } \mathrm{K} \text { index and antioxidants (R) }\end{array}$} \\
\hline & $\mathrm{A}^{*}$ & $\mathrm{Ph}^{*}$ & $\mathrm{~L}-\mathrm{AA}^{*}$ & & $\begin{array}{l}\mathrm{A}^{*} ; \\
\mathrm{R}_{1}\end{array}$ & $\begin{array}{l}\mathrm{Ph}^{*} ; \\
\mathrm{R}_{2}\end{array}$ & $\mathrm{AA}^{*} ; \mathrm{R}_{3}$ & $\begin{array}{c}\text { The total } \\
\text { antioxidants } \\
\text { content, } \mathrm{R}_{\mathrm{s}}\end{array}$ \\
\hline \multicolumn{9}{|c|}{ Fresh strawberries } \\
\hline 1 & $20.7 \pm 0.53$ & $290.5 \pm 9.47$ & $39.4 \pm 0.24$ & $16.3 \pm 0.65$ & 0.78 & 0.92 & 0.84 & 0.93 \\
\hline 2 & $21.7 \pm 0.39$ & $157.0 \pm 8.93$ & $35.2 \pm 0.37$ & $15.0 \pm 0.38$ & 0.99 & 0.99 & 0.67 & 0.97 \\
\hline 3 & $41.9 \pm 0.47$ & $251.87 \pm 5.70$ & $45.7 \pm 0.30$ & $13.7 \pm 0.25$ & 0.88 & 0.99 & 0.96 & 0.99 \\
\hline \multicolumn{9}{|c|}{ Frozen strawberries 3 months } \\
\hline 1 & $16.7 \pm 0.13$ & $165.44 \pm 8.35$ & $34.1 \pm 0.35$ & $3.21 \pm 0.28$ & 0.80 & 0.99 & 0.80 & 0.99 \\
\hline 2 & $19.2 \pm 0.54$ & $96.5 \pm 7.60$ & $28.9 \pm 0.42$ & $3.5 \pm 0.45$ & 0.67 & 0.95 & 0.88 & 0.90 \\
\hline 3 & $37.5 \pm 0.32$ & $230 \pm 2.60$ & $32.5 \pm 0.34$ & $8.10 \pm 0.23$ & 0.94 & 0.99 & 0.99 & 0.99 \\
\hline \multicolumn{9}{|c|}{ Frozen strawberries 10 months } \\
\hline 1 & $14.9 \pm 0.43$ & $96.9 \pm 9.51$ & $26.3 \pm 0.44$ & $1.23 \pm 0.32$ & 0.99 & 1.00 & 1.0 & 0.94 \\
\hline 2 & $16.6 \pm 0.65$ & $84.5 \pm 7.57$ & $26.5 \pm 0.18$ & $2.7 \pm 0.28$ & 0.98 & 1.00 & 0.83 & 1.00 \\
\hline 3 & $36.7 \pm 0.14$ & $164.5 \pm 3.12$ & $27.5 \pm 0.15$ & $7.72 \pm 0.15$ & 0.99 & 1.00 & 0.99 & 1.00 \\
\hline
\end{tabular}

*where: A - Anthocyans, Ph - Total Polyphenols, AA - L-hydroascorbic acid. 


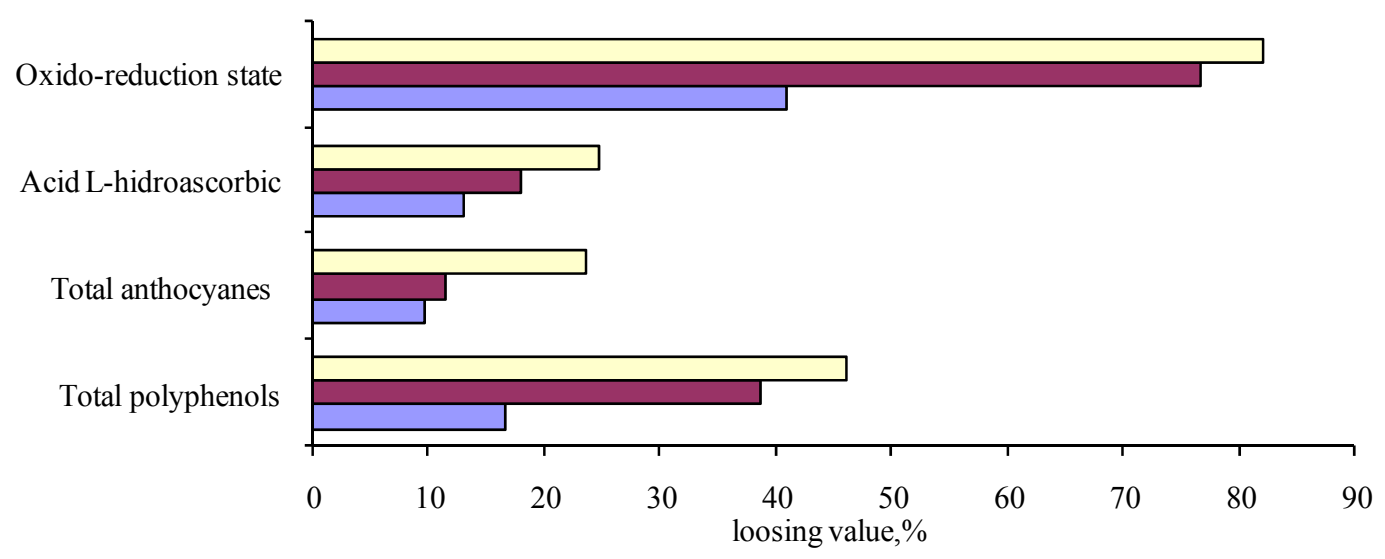

$\square$ After 10 months $\square$ After 6 months

Figure 1. Phisical-chimical index degradation rate in frozen strawberries

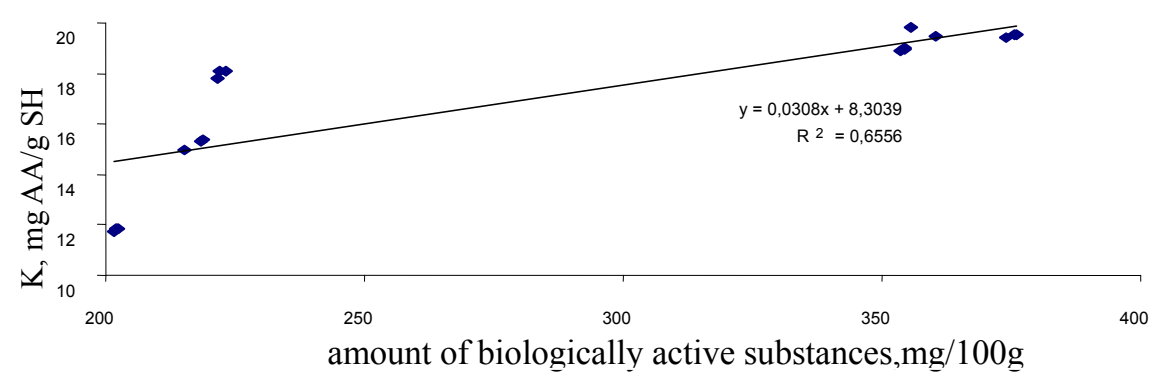

Figure 2. Kinetics of Antioxidant Activities

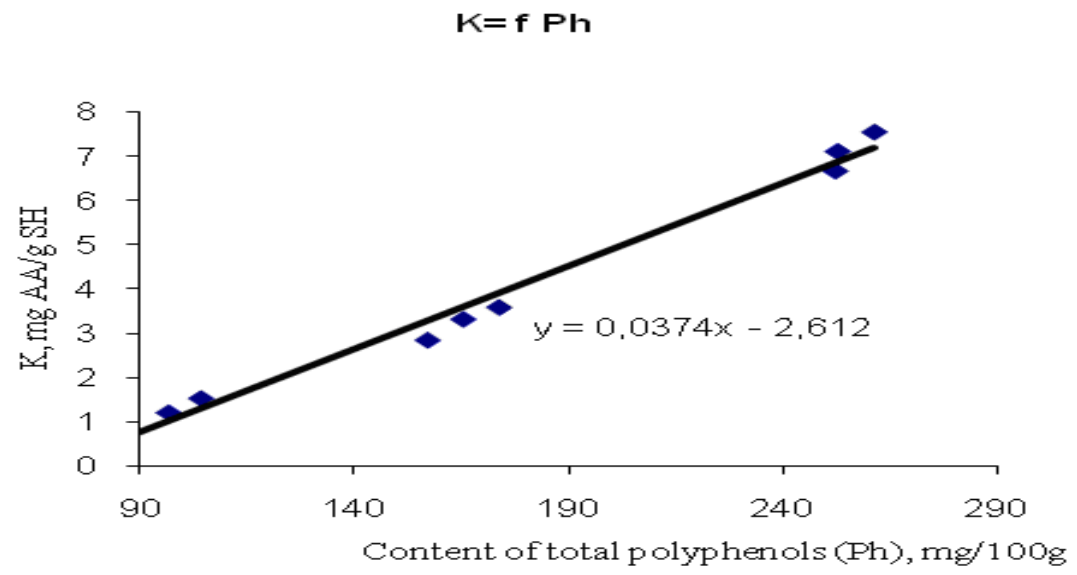

Figure 3. The correlation between $\mathrm{K}$ index and polyphenols content in frozen strawberries 


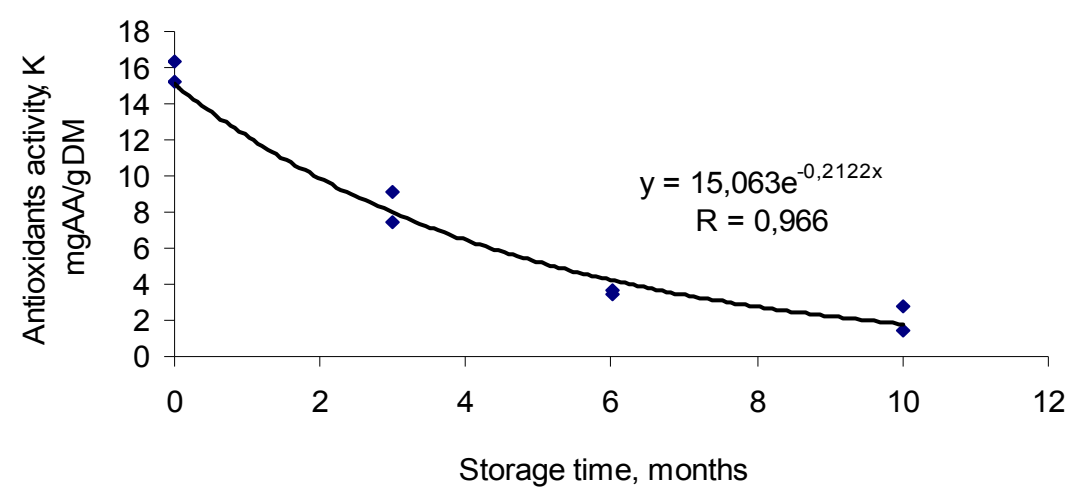

Figure 4. The evolution of antioxidants activity in frozen strawberries

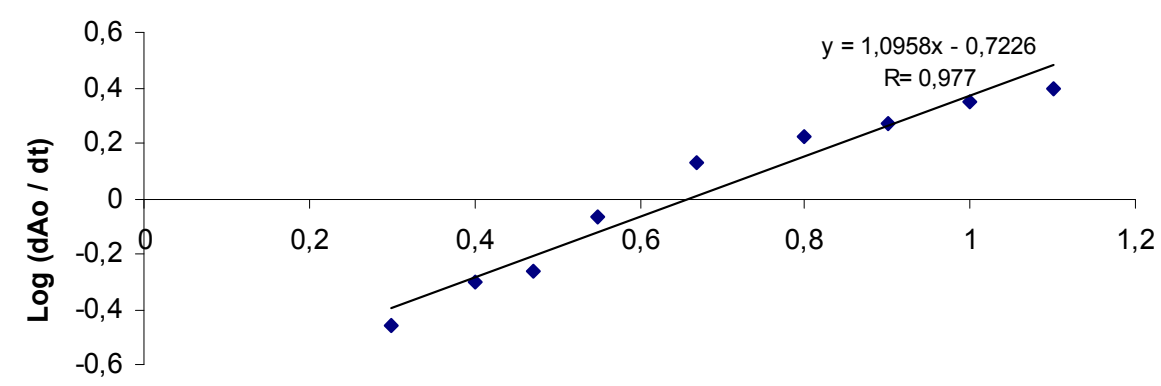

$\operatorname{Lg}$ Ao

Figure 5. Kinetics of Antioxidant Activities

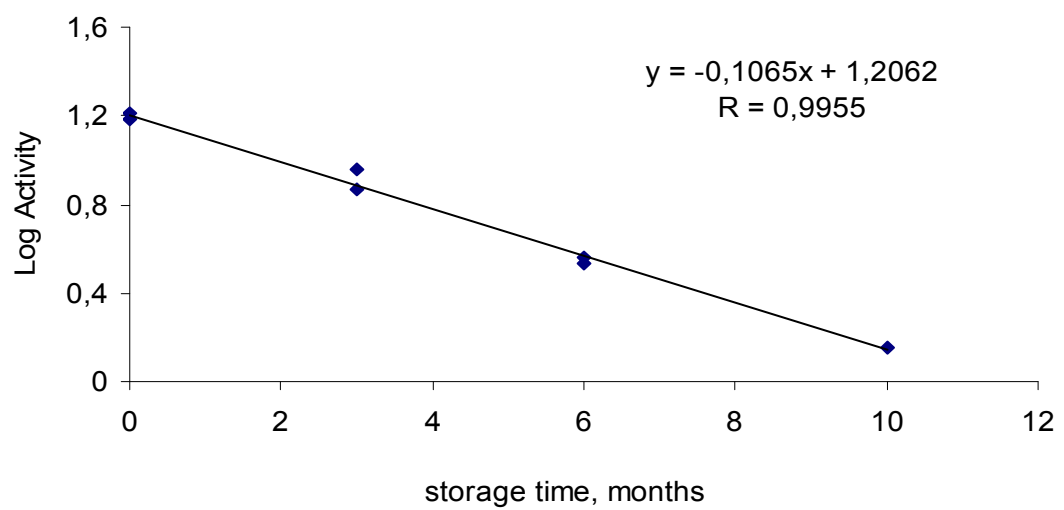

Figure 6. Changes in antioxidants activity during the storage of frozen strawberries 


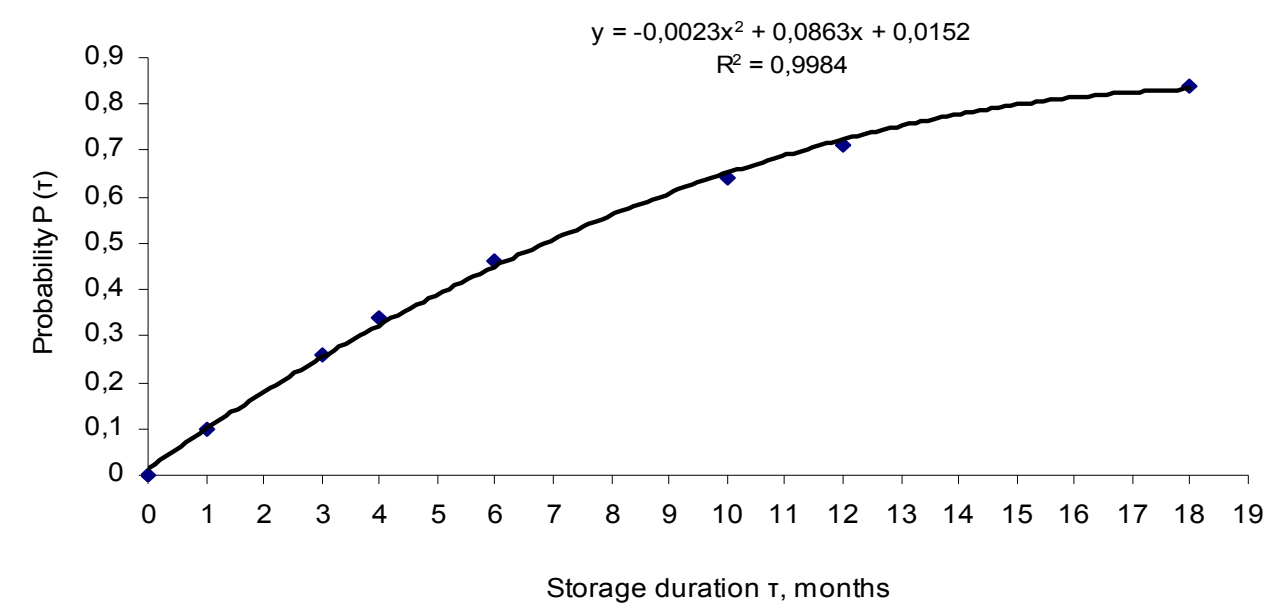

Figure 7. The probability of quality loss of frozen strawberries during storage 